\title{
SEISMIC ACCESS IsSUES
}

\section{Allan D. Nielsen, Q.C. AND Christopher B. MANDERVILlE*}

This article examines the legal relationship between an owner of petroleum and natural gas rights and other interested parties when it comes to seismic operations. While rules on access to Crown lands and freehold surface have been rather clearly delineated, the rules pertaining to seismic operations on freehold land are not as clear. Case law from the United States is helpful, though limited in scope, mostly old, and sometimes based on different ownership theories.
Cet article examine le rapport juridique qui existe entre le détenteur de droits pétroliers et gaziers et les autres parties intéressées dans le cas d'exploitations sismiques. Bien que les règles concernant les terres de la Couronne et les surfaces en propriété franche soient clairement délimitées, les règles concernant les exploitations sismiques sur les surfaces en propriété franche ne sont pas claires. La jurisprudence américaine est utile, bien que limitée dans sa portée en plus d'ètre ancienne et de reposer parfois sur des théories différentes de la propriété.

\section{TABLE OF CONTENTS}

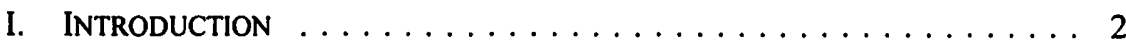

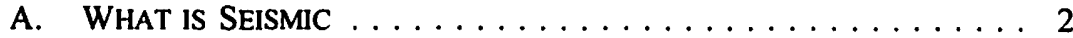

B. IDENTIFICATION OF APPROPRIATE CASE LAW ......... 3

II. GETTING ON THE LAND $\ldots \ldots \ldots \ldots \ldots \ldots \ldots \ldots \ldots$

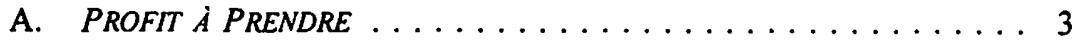

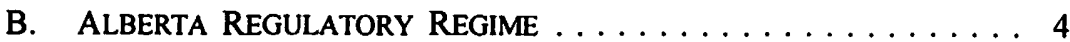

C. NOTE ON EFFECTS OF FREEDOM OF

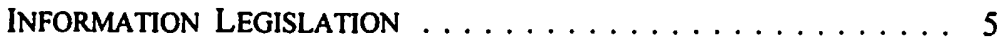

D. Private Landowner Agreements $\ldots \ldots \ldots \ldots \ldots \ldots \ldots$

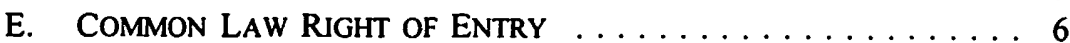

III. OTHER INTERESTS INVOLVED $\ldots \ldots \ldots \ldots \ldots \ldots \ldots \ldots \ldots$

A. OTHER INTERESTS DEFINED $\ldots \ldots \ldots \ldots \ldots \ldots \ldots \ldots$

B. TENANCY IN COMMON $\ldots \ldots \ldots \ldots \ldots \ldots \ldots \ldots$

C. OTHER INTERESTS DISCUSSED $\ldots \ldots \ldots \ldots \ldots \ldots \ldots$

IV. GeophySICAL TRESPASS $\ldots \ldots \ldots \ldots \ldots \ldots \ldots \ldots \ldots \ldots$

A. Surface OWNERS $\ldots \ldots \ldots \ldots \ldots \ldots \ldots \ldots \ldots \ldots \ldots \ldots$

B. Petroleum and Natural GaS

OWNERS AND LesSEES $\ldots \ldots \ldots \ldots \ldots \ldots \ldots \ldots \ldots$

C. Other Possible CAUSES of Action $\ldots \ldots \ldots \ldots \ldots \ldots 13$

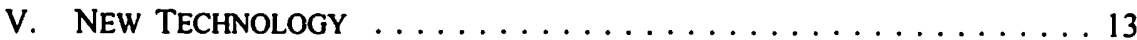

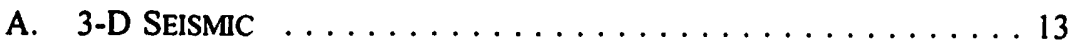

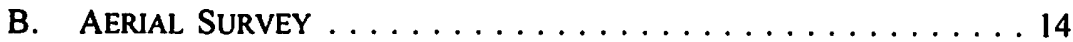

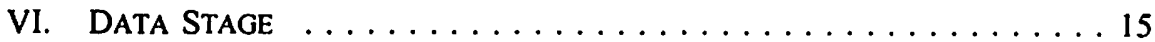

A. Note on the Alberta ENvironment Practice . . . . . . 15

B. SEISMiC DATA AS CONFIDENTIAL INFORMATION $\ldots \ldots \ldots \ldots 15$

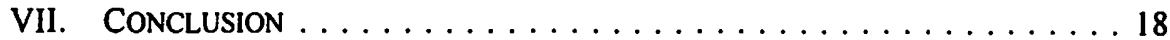

Allan D. Nielsen is a partner with the firm of Borden Ladner Gervais LLP in Calgary, Alberta. Christopher B. Manderville is an associate also with the Calgary office of Borden Ladner Gervais LLP. 


\section{INTRODUCTION}

This article will explore the relationship between an owner of petroleum and natural gas rights vis-à-vis other interested parties with respect to seismic operations and seismic information. It will discuss the rights an owner of petroleum and natural gas rights has in the initial exploration stage and at the data stage of the exploration operation. It will also discuss the relationship between the petroleum and natural gas rights owner and land owners, working interest owners, owners of rights in another petroleum or natural gas in the same horizon, and with the gatherers of geophysical data. Finally, this article will discuss seismic data as confidential information and the responsibilities that flow from such a characterization.

\section{A. What is SeISMic}

It is useful to set out a few definitions related to seismic exploration and data. The Dictionary of Geological Terms ${ }^{1}$ defines "seismic exploration" as follows:

The use of artificially generated seismic waves in the search for economic deposits such as salt or oil and gas, or in engineering studies, e.g. determining the depth to bedrock.

"Seismic" is defined in the same text ${ }^{2}$ as

[p]ertaining to an earthquake or earth vibration, including those that are artificially produced.

In A Dictionary for the Petroleum Industry "seismic data" is defined as

detailed information obtained from earth vibration produced naturally or artificially.

And perhaps the most helpful definition is that of "seismic survey," which is set out in A Dictionary for the Petroleum Industry as

an exploration method in which strong low-frequency sound waves are generated on the surface or in the water to find subsurface rock structures that may contain hydrocarbons. The sound waves travel through the layers of the earth's crust; however, at formation boundaries some of the waves are reflected back to the surface where sensitive detectors pick them up. Reflections from shallow formations arrive at the surface sooner than reflections from deep formations, and since the reflections are recorded, a record of the depth and configuration of the various formations can be generated. Interpretation of the record can reveal possible hydrocarbon-bearing formations.

R.L. Bates \& J.A. Jackson, eds., The American Geological Institute Dictionary of Geological Terms 3d ed., (New York: Doubleday, 1984) s.v. "Seismic Exploration."

Ibid. s.v. "seismic."

The University of Texas at Austin, A Dictionary for the Petroleum Industry, 3d ed., (Austin: Petroleum Extension Service, 1999) s.v. "seismic data."

Ibid. s.v. "seismic survey." 
In laymen terms, seismic exploration involves setting off explosive charges in holes drilled in the ground for that purpose or striking the ground and measuring the ensuing vibrations. The information gathered from the vibrations may identify the existence or absence of hydrocarbon-bearing formations.

\section{B. IDENTIFICATION OF APPROPRIATE CASE LAW}

Where Canadian law is silent on issues discussed herein, American jurisprudence will be discussed. However, American law, it must be remembered, is only helpful to the extent the jurisdiction from which the law is taken has theories of ownership of petroleum and natural gas rights not in conflict with Canadian theories of ownership of petroleum and natural gas rights. As the Court of Appeal of Alberta stated in Bank of Montreal v. Dynex Petroleum Ltd:

\footnotetext{
American case law, however, can be useful when considering issues not previously decided in Canada. particularly, in the context of oil and gas. However, as noted by Fruman J. (as she then was) in Anderson v. Amoco Canada Oil \& Gas [(1988), 63 Alta. L.R. (3d) I (Alta. Q.B.)], at p. 41:

\begin{abstract}
American case law must be read with care. Unlike Canada, many U.S. states have adopted theories of ownership. Cases decided in one state may not apply in others because they differ in their classification of the interests landowners hold in oil and gas.... Because of the differing theories of ownership among various states, it is often inappropriate to extrapolate decisions form a specific state as representing American oil and gas law generally. ${ }^{5}$
\end{abstract}

\section{GetTing ON THE LAND}

This Part will explore the necessary steps involved in obtaining the appropriate permissions to shoot seismic on land in Alberta. Before launching into a discussion of the appropriate steps necessary to get the seismic equipment and personnel on the land to conduct operations, it is important to be reminded of the rights possessed by a lessee of petroleum and natural gas. These rights exist as a result of the characterization of this interest in Canada as a profit à prendre.

\section{A. PROFIt À PRENDRE}

It is clear that in Alberta a petroleum and natural gas rights owner has an interest in the land characterized as a profit $\grave{a}$ prendre. ${ }^{6}$ Encompassed in a profit $\grave{a}$ prendre is a right to sever those substances from the soil of another. The rights involved in a profit $\dot{a}$ prendre are outlined as follows: 
The incidents of a profit à prendre of particular significance in relation to the interest in oil and gas may be summarized as follows: The right is the right to enter the land of another and to take some profit from the soil or any part of the soil itself. ${ }^{7}$

The right to conduct seismic operations may be ancillary to the right to exploit the soil for petroleum and natural gas, such that the petroleum and natural gas rights owner is able to determine whether or not there exists petroleum and natural gas substances in a quantity worth producing. There may be, in Alberta, a presumption that the petroleum and natural gas rights owner has a right to explore the subsurface.

\section{B. Alberta Regulatory Regime}

To obtain the right to explore on Crown or private lands in Alberta the governing legislation is the Exploration Regulation ("Regulation"). Section 3 of the Regulation discusses who has the right to conduct exploration. That section reads as follows:

Subject to this Part, an exploration approval authorizes the licensee for the program of exploration, and any person authorized by the licensee to conduct the program, to use the land designated in the exploration approval in accordance with the terms and conditions of the approval.

The Regulation defines licensee as follows:

1(v) "Licensee", when used in relation to a program of exploration, means the holder of the exploration licence under which the program of exploration is conducted;

To obtain the exploration licence the Regulation provides that an application must be made to Alberta Environment Land and Forest Service, Land Administration Division using an Application for Exploration License and/or Permit form. ${ }^{9}$ The form requires that an applicant must provide, inter alia, the location where the proposed seismic is to be shot, the energy source, the type of equipment to be used, whether there are any water bodies nearby, and how many kilometres long the shoot is going to be..$^{10}$ It also requires an applicant to distinguish whether a three-dimensional ("3-D") or two-dimensional ("2-D") seismic program will be used." Once an applicant receives approval, there are, inter alia, geophysical field reports that must be completed throughout the program and submitted to Alberta Environment Land and Forest Service, Land Administration Division. $^{12}$

Halsbury's Laws of England, vol. 14, 4th ed. (London: Butterworths, 1975) at 115-21, paras. 240-52.

- Alta. Reg. 214/98 (made under the Forests Act, Mines and Minerals Act, Public Highways Development Act, and the Public Lands Act).

, Ibid., s. 8(1).

I1" Ibid., ss. 10(3)-(4).

"Ibid., s. 10(4)(b).

$12 \quad$ lbid., s. 22. 
The Regulation provides that no person shall conduct exploration on lands in Alberta without the consent of the person having lawful possession of that land. ${ }^{13}$ Where the land is private land or leased land (i.e., grazing lease) from the Crown, consent of the owner or lease holder must be obtained. ${ }^{14}$ If the land is Crown land and there are no other interested parties, permission must be received from the appropriate Crown agency, ministry or agent thereof. ${ }^{15}$ Where the lands are within the boundaries of a Metis settlement, the Regulation requires that consent be obtained from both the "settlement council and the Metis Settlements General Council."16 Where lands are within an Indian Reserve, s. 6 of the Indian Oil and Gas Regulations, $1995^{17}$ provides for a licensing process whereby the applicant must obtain approval from the Executive Director of Indian Oil and Gas Canada, Department of Indian Affairs and Northern Development.

Given the foregoing, it is clear that one cannot conduct seismic operations in the Province of Alberta without having the consent of the person interested in the surface portion of the land. However, while the Regulation deals with surface rights of access, it is silent on subsurface rights or approvals. ${ }^{18}$ Whereas most of the subsurface petroleum and natural gas in Alberta is owned by the Crown, and as such is dealt with by Alberta Environment, this article will focus more on freehold land and petroleum and natural gas rights that are privately held.

\section{NOTE ON EFFECTS OF FREEDOM OF INFORMATION LEGISLATION}

While the Alberta Environment application forms require companies to give detailed information about their proposed seismic program, there is little danger in third parties obtaining such information given the recent release of Order 2000-034 from the Office of the Information and Privacy Commissioner. ${ }^{19}$ That Order states that s. 49(1) of the Mines and Minerals $A c t^{20}$ does not permit disclosure of records that would reveal geological or geophysical work. Therefore, substantially all parts of any seismic program submitted to Alberta Environment will be protected.

\section{Private Landowner AgReements}

As mentioned above, there are a number of forms to be used in connection with exploration on Crown lands, but where the land is private there are no statutory regimes or forms. However, the Canadian Association of Geophysical Contractors ("CAGC") has a standard form agreement called a Permit to Conduct Geophysical Operations ("Permit").

Ibid., s. 4(1)(a).

Ibid., s. 4(1)(d).

lbid., ss. 4(l)(b)-(d).

Ibid., s. 4(1)(h).

S.O.R./94-753.

Section 4(3) requires that persons proposing to conduct seismic operations get consent "where that consent is required by law." Whether this section could be construed to contemplate subsurface owners is unknown.

Online: Office of the Information and Privacy Commissioner Alberta <oipc.ab.ca/whatsnew/welcome. $\mathrm{htm}>$ (date accessed: 20 December 2000).

R.S.A. 1980 , c. M-15. 
The Permit provides for a number of eventualities that may occur in carrying out exploration operations. While there is no requirement to use the Permit, it has been approved by the CAGC, the Canadian Association of Petroleum Producers ("CAPP"), and the Small Explorers and Producers Association of Canada ("SEPAC"). CAGC suggests the Permit enjoys widespread use throughout Alberta and other parts of Western Canada.

In entering agreements with landowners, a petroleum and natural gas lessee is wise to cover off all eventualities that may arise as a result of the seismic operations on the relevant land. The permit is a good example of indemnities and limitations of liabilities and agreements as to compensation in the event of damage beyond reasonable wear and tear. In Part IV there will be a discussion of circumstances wherein seismic operations are conducted on land without the appropriate consent.

\section{E. COMmON LAW RIGHT OF ENTRY}

At common law a petroleum and natural gas lessee had a right to enter on the land of another without their consent to avail himself of his subsurface interest. Dea J. expresses the rationale underlying this principle in Cabre Exploration Ltd. v. Arndt succinctly wherein he states:

At common law, upon the severance of the title to the minerals from the title to the surface, a right of entry arose at law... The rationale is that unless the owner of the minerals was to enjoy a right to enter upon the surface to work the minerals that severance would not occur. ${ }^{21}$

In that same case Dea J. goes on to say that the Surface Rights $A c t^{22}$ has altered that common law right such that there is no absolute right for the owner of a profit à prendre to enter the land of another without their consent. ${ }^{23}$ The right at common law to enter on the land above one's mineral interest may have included a right to explore to determine whether the interest was worth exploitation. If that assertion is correct, the alteration of the right of access under the Surface Rights Act may be akin to the requirement of consent in the exploration of lands as required in the Regulation. Perhaps an argument could be made to the effect that in both cases there was a right at common law and that in both cases that right was altered by statute or regulation. Thus it is suggested that the right of a petroleum and natural gas lessee to explore may have existed at common law under the auspice of a profit à prendre to allow the subsurface rights owner to exercise his rights. The reason it is important to characterize the ability to conduct seismic exploration as a right that exists ancillary to a profit à prendre is to assure the petroleum and natural gas rights lessee the ability to determine whether his interest is worthwhile. Surely it would make no sense to deny the petroleum and natural gas rights lessee the ability to evaluate his subsurface interest.

Support for the assertion that there may exist at law the right of a petroleum and natural gas lessee to explore his interest is found in American decisions. The Federal

23. Supra note 21 at 143-44. 
Court, in Yates v. Gulf Oil Corp. ${ }^{24}$ held that there exists an implied right of the petroleum and natural gas rights owner to enter the lands under which his subsurface rights exist for the purpose of conducting geophysical exploration. The court in Shell Petroleum Corp. v. Puckett, ${ }^{25}$ without deciding the issue, expressed the opinion that a lease for petroleum and natural gas carried with it a "nonexclusive privilege" of testing the land by geophysical methods.

\section{OTHER INTERESTS INVOLVED}

\section{A. OTHER INTERESTS DEFINED}

Other interested parties that a subsurface lessee may need to be aware of in conducting seismic operations are the owners and lessees of other mineral substances in the same horizon (i.e., coal or gas where you are the oil owner) and parties with an interest in the same substance in the same horizon (i.e., your partners).

\section{B. Tenancy in Common}

To determine the rights and responsibilities between the interested parties listed above, it first must be determined the relationships they have at law. The relationship between owners in the same subsurface rights in the same horizon is characterized as a tenancy in common. A tenancy in common, in the absence of an express term to the contrary, is presumed to exist pursuant to s. 8 of the Law of Property Act. That section reads as follows:

When, by letters patent, notification, transfer, conveyance, assurance, will or other assignment, land or an interest in land is granted, transferred, conveyed, assigned or bequeathed to 2 or more persons, other than as executors or trustees, in fee simple or for any less estate, legal or equitable, those persons take as tenants in common and not as joint tenants unless an intention sufficiently appears on the face of the letters patent, transfer or conveyance, will or other assurance that they should take as joint tenants. ${ }^{26}$

Simply put, this section presumes that where more than one party has an interest by way of a lease or other agreement, from the owner or a lessee of the petroleum and natural gas rights, those parties are tenants in common unless the agreement transferring the interest clearly states otherwise.

Additionally, industry practice seems to be consistent with tenancy in common. Support for this proposition is found in the Canadian Association of Petroleum Landmen ("CAPL") 1997 Farmout \& Royalty Procedure. In clause 1.02 of this Procedure, Article XV of the 1990 CAPL Operating Procedure is incorporated by reference. The relevant part of Article XV is reproduced below. 
The rights, duties, obligations and liabilities of the parties hereunder shall be separate and not joint or collective, not joint and several, it being the express purpose and intention of the parties that their interests in the joint lands and in the wells, equipment, production facilities and property thereon held for the joint account shall be held as tenants in common, subject to the modification of the incidents thereof that are provided in this Operating Procedure.

Thus the standard industry contracts recognize the relationship of the parties as one of tenants in common.

Since the subsurface owners are tenants in common they have certain rights as against each other. Without getting into detail, there are statutory rights of a tenant in common for an accounting from another tenant. ${ }^{27}$ Additionally, where the subject matter of the tenancy in common is sold, "[a]n order of partition or division of sale proceeds proportionate to the contribution of the parties is entirely appropriate." 28

The law governing actions against other tenants in common is encapsulated in Part 3 of the Law of Property Act. That part is applicable to a profit à prendre by virtue of s. 14(e) which defines "land," for the purposes of that part, as expressly including a profit à prendre. ${ }^{29}$

The question then becomes whether seismic information may be classified as a part of the estate of the tenants in common. Or, more specifically, whether data delineating the existence and extent of the profit à prendre is part of the profit à prendre. If the argument that the right to explore is part of the profit a prendre is correct, then that may assist the characterization of the data gathered from such exploration as being part of the estate of the tenants in common. Such a finding would have the effect of ensuring the rights of all of the interested parties in the data gathered. Additionally, where the seismic data is characterized in this manner, in the event one party licenses or otherwise transfers seismic information without the permission of the other tenants in common, that party may be open for an action for an accounting or compensation to the extent of the interest of the party claiming relief by nature of the Law of Property Act.

\section{OTHER INTERESTS DISCUSSED}

This part of the article will explore the relationship between the petroleum and natural gas owner, and the landowner, other resource owners, and working interest owners.

2x The Canadian Encyclopedic Digest (Western), vol. 30, 3d ed. (Toronto: Carswell, 1979) at 125-35, para. 237. 


\section{HORIZONTAL INTEREST OWNERS}

This section deals with the rights an owner of the oil in a well but not of the gas has against the owner of the gas (or oil and gas owner as against the owner of a coal seam through which one must shoot seismic in operations to evaluate the petroleum and natural gas zone). That relationship has not been dealt with by the courts as at the date of this article. The American courts, on the other hand, have begun dealing with exactly that problem.

It is settled law in some American jurisdictions that the owner of the deep rights has a right to log or explore through the shallow rights owner's zone in drilling operations. ${ }^{30}$ At least one American author takes this case and those following it to support "the proposition that the owner of deep rights has the right of access through the shallow zones to conduct geophysical operations to evaluate the deep structures." 31 If, on the other hand, a shallow rights owner gains information on the deep rights, the American courts may consider that act as geophysical trespass. ${ }^{32}$

The case law in the United States recognizes the reality that the deep rights owner is not able to exercise his rights in the subsurface substances without passing through the shallow rights owner's zone. The logical extension of this may be that whatever data is needed from the shallow zone to interpret the deeper zone may be used by the deep rights owner. Additionally, the discussion in Part IV of this article on geophysical trespass may shed more light on this issue.

Canadian courts have not dealt explicitly with the issue of competing rights as between horizontal owners in a conflict over seismic exploration rights. A party who feels there has been actionable impropriety in the exploration process may attempt an action under the Part 3 of the Law of Property Act or sue for geophysical trespass. The trouble with either action, assuming the courts in Canada will hear either action and assuming success, is the difficulty of quantifying damages.

\section{OTHER WORKING INTERESTS}

"Working interest" is defined in A Dictionary for the Petroleum Industry as

the interest in oil or gas that includes responsibility for all drilling, developing, and operating costs. Also called leasehold interest, operating interest. ${ }^{33}$

An owner who granted rights to another party by way of a farmout agreement may have seismic information on the area over which the farmout is granted. It is in these circumstances that an examination of the rights of the parties to the formation information

w Chartiers Block Coal Co. v. Mellon, 25 A. 597 at 599 (Pa. 1893) [hereinafter Mellon].

" H.L. Blomquist III, "Geophysical Trespass? The Guessing Game Created by the Awkward Combination of Outmoded Laws and Soaring Technology" (1996) 48 Baylor L. Rev. 21 at 42-43.

32 Phillips Petroleum Co. v. Cowden, 241 F.2d 586 at 590 (5th Cir. 1957) [hereinafter Cowden].

3. Supra note 3, s.v. "working interest." 
is undertaken. Part of the responsibility of the farmee will be to log the well. While well logging is not exactly seismic activity, it is the subsurface measure of a zone to the end of evaluating production capabilities, and the information gained is similar in that light. The farmee could potentially gain information on the production capabilities in his capacity of operator. Since the working interest owners tenants in common, either by farmout agreement or by the Law of Property Act presumption, they then have the rights as well as responsibilities as outlined above respecting what they may and may not be able to do with the seismic information gained, whether through logging or otherwise.

There are no apparent bars on who, among the interest owners, may request the seismic be shot. Whereas the practice in the industry may be to achieve consensus as between all of the interest holders, there is no requirement that 100 percent or even 50 percent of the interest holders sign on. It is probably sufficient for a party that holds an interest, whatever the percentage, to retain a seismic company to conduct exploration operations.

\section{Geophysical Trespass}

This portion of the article will deal with consequences that may result from the activities of geophysical contractors while conducting seismic operations when a surface owner, freehold petroleum and natural gas owner or petroleum and natural gas lessee is of the view that those activities have wrongfully interfered with the rights of such individuals. The causes of action resulting from such interference arise in tort, mostly in nuisance and trespass, both of which areas will be examined in some detail. Some other areas of tort will also be briefly reviewed in an attempt to determine whether or not they might provide relief against geophysical misconduct. There are very few reported decisions of the Canadian courts in this area, so the law in the United States will be relied upon in certain respects as a guide as to what the outcome might be in Canada in similar circumstances.

\section{A. SURFACE OWNERS}

The facts before the Supreme Court of Alberta in Phillips v. California Standard Company $^{34}$ were that California Standard did some seismograph work on certain lands in late October of 1956. The work included shooting seismic near the lands of the plaintiff, Phillips, who owned and operated a farm near Calmar. The work was not done on the land belonging to Phillips but on land immediately adjacent and on a neighbouring road allowance. There was no suggestion that any legislation or regulations were breached in doing the work. Phillips had a water well located only 770 feet from the nearest shot hole and within hours of the explosions he "drew off some 2 pails of water which was highly discoloured and highly odiferous, smelling highly of sulphur and, as said by some of the witnesses, like the smell of rotten eggs." ${ }^{35}$ Phillips sued, and the Court easily concluded that the damage to the well was the result of the seismic work. The action was brought in trespass, and after an analysis of the law the Court held that as no physical entry by the defendants took place there was no trespass. However, the Court found that 
the vibrations from the explosions contributed a nuisance and delivered a judgment for damages in favour of Phillips.

An unreported case, Reilly v. Pan American Petroleum Corp. ${ }^{36}$ had very similar facts, and that court came to a similar conclusion. Kirby J. quoted the Phillips case with approval and added:

I am of the opinion that the vibrations set up by these explosions and transmitted to the strata supplying the flow of water through this artesian spring situated on the defendant's lands do in law give a cause of action for nuisance. ${ }^{37}$

These two Alberta decisions show that when there has not been a physical presence by a seismic operator on a plaintiff's lands an action will lie in nuisance rather than trespass because vibrations travelling from other lands do not constitute trespass. They also show that compliance with all regulatory requirements will not protect a seismic operator if its activities result in damages to neighbouring lands.

The position in the United States regarding surface owners is the same as Canadian law as far as trespass is concerned. The leading case in this area in the United States is Kennedy v. General Geophysical Co. ${ }^{38}$ where the plaintiff denied the defendant permission to shoot seismic tests on the plaintiff's land. The defendant, therefore, conducted the operations on the neighbouring lands. The plaintiff brought an action in trespass. The Texas Court dismissed the claim because there was no evidence of physical trespass, and mere vibrations under the plaintiff's land did not constitute trespass.

\section{B. Petroleum and Natural Gas OWNers and Lessees}

The courts in Canada have not considered what rights the freehold owner of petroleum and natural gas has if the surface owner of the same lands permits seismic work to be done on those lands without the permission of that freehold owner. Nor have the Canadian courts dealt with the situation wherein a lessee of that petroleum and natural gas, or of one formation thereof, has not consented to that exploration. However, there are decisions in the United States which may provide guidance in these areas.

It is well established in the United States that the owner of a mineral right may recover damages for an unauthorized geophysical survey separate and apart from any right the surface owner may have. ${ }^{39}$ The reasoning of the Louisiana courts in the leading cases of Layne Louisiana Co. v. Superior Oil Co. ${ }^{40}$ and Holcombe v. Superior Oil Co. ${ }^{41}$ was that Holcombe's freehold mineral interests were separate and apart from the surface rights of Layne Louisiana Co., and that those rights could be protected in the same manner as the

(22 January 1964), Calgary 69939 (Alta. Div. Ct.) [hereinafter Reilly].

This quotation from the judgment is extracted from M.G. Van Vliet et al., "Geophysical Damage to Property and Related Problems" (1966) 5 Alta. L. Rev. 29 at 34.

213 S.W.2d 707 (Tex. Civ. App. 1948).

O.L. Anderson, "Geophysical 'Trespass' Revisited" (1999) 5 Tex. Wesleyan L. Rev. at 137.

26 So.2d 20 (La. 1946).

35 So.2d 457 (La. 1948) [hereinafter Holcombe]. 
surface rights; that is, by way of an action in trespass. Superior had conducted seismic activity on lands where the surface was owned by Layne Louisiana Co. and the minerals were owned by Holcombe. Neither plaintiff had consented to the seismic survey, and each was successful in separate actions for trespass. In reaching its decision in the Holcombe case the Court found that the right to geophysically explore for minerals is a valuable right and that it is part of the exploration rights owned by the owner of the minerals. This reasoning was adopted by the Texas court in Cowden discussed above.

If the reasoning in the above cases was adopted by the Alberta courts it would provide a clear cause of action to freehold petroleum and natural gas owners against geophysical activities on the surface under which their lands lie which they have not authorized. However, a problem exists: Texas considers mineral interests to be corporeal; whereas in Alberta petroleum and natural gas interests are incorporeal. The importance of this distinction is illustrated by the case of Ohio Oil Co. v. Sharp ${ }^{42}$ where one of the judges reasoned that since petroleum and natural gas ownership in Oklahoma (where the rights subject to that action were located) is an incorporeal hereditament, or a profit $\dot{a}$ prendre, it cannot be the subject of an action in trespass. The comments made by the judge in Sharp were dicta, as the majority of the Court assumed trespass had taken place when the unauthorized geophysical work had been done and decided the case on other grounds.

It seems obvious that in Alberta, as in Louisiana, Texas and Oklahoma, the ownership of a petroleum and natural gas interest is a valuable right separate from the ownership of the surface, and if that right is interfered with there should be a remedy and that remedy should be in trespass. Trespass applies to real property (such as a profit à prendre) and does not require proof of damage, ${ }^{43}$ which is sometimes difficult to show in situations of geophysical interference. The fact that the interests in question are incorporeal could provide an Alberta court with a basis on which to deny the owner of a freehold petroleum and natural gas right with a remedy in trespass where geophysical interference occurs from the surface of those same lands.

In the United States the rights and remedies of the lessee of petroleum and natural gas vis-à-vis geophysical work done respecting his interests without his consent are substantially the same as those of the petroleum and natural gas owner ${ }^{44}$ There is, however, one additional fact to be considered - the wording of the lease itself. If it reserves any exploration rights to the freehold petroleum and natural gas owner or does not provide the lessee with the exclusive right to all the petroleum and natural gas, it is possible that the lessee will not have the authority to prevent its rights from being geophysically explored from the surface. Therefore, the lessee of other horizons or other kinds of mineral rights will have right of access through a lessee's leased horizons to conduct geophysical operations if they are necessary for or incidental to the rights of the 
other lessee. ${ }^{45}$ The use of such information once it is obtained is dealt with elsewhere in this article.

\section{Other Possible Causes of action}

The obvious causes of action available to surface owners for geophysical misconduct are in nuisance and, if there is physical entry, trespass. Petroleum and natural gas owners and lessees are likely to have remedies in trespass. Some other torts may also be available in certain circumstances.

Any expectation that a surface owner might have a chance of a successful action against a geophysical contractor based on the principles in Rylands v. Fletcher ${ }^{46}$ was dealt with in the Alberta cases of Phillips and Reilly. In both Phillips and Reilly it was held that the principles of Rylands v. Fletcher do not apply to geophysical vibrations.

In some situations it may be that a geophysical operator has interfered with contractual relations. This could be the case if he convinces a lessor of petroleum and natural gas to allow geophysical survey thereof even though the lessor has leased exclusive right thereto to another non-consenting party. Several American articles on geophysical trespass suggest that a petroleum and natural gas owner might in some circumstances have an action for wrongful appropriation of trade secrets when authorized geophysical activity has taken place. $^{47}$

\section{NEW TECHNOLOGY}

Since the mid-1980s, 3-D seismic has become a popular method of analysis, and the technology related to conducting magnetic surveys from the air has improved. Both of these advances give rise to new legal issues associated with the rights of petroleum and natural gas freehold owners and lessees.

\section{A. 3-D SEISMIC}

One of the primary differences between 2-D seismic and 3-D seismic is that 2-D is collected along a straight line whereas 3-D uses a grid pattern for placement of sources and receivers. 3-D usually covers a larger geographical area, which means that more mines and mineral owners and lessees will potentially be affected. It also means that petroleum and natural gas will likely be included in the survey results that are not located beneath the lands on which the sources and receivers are placed. ${ }^{48}$ This could mean that in order to avoid a suit, the consent of each potentially affected petroleum and natural gas

Mallon Oil Co. v. Bowen/Edwards Associates, Inc., 965 P.2d 105 (Colo. 1998) [hereinafter Mallon v. Bowen/Edwards].

(1868), L.R. 3 H.L. 330.

Blomquist, supra note 31 at 48-49.

See Chapter 16 "Proceedings of the Rocky Mountain Mineral Law Forty-Second Annual Institute" (18-20 July 1996) (1996) 42 Rocky Mt. Min. L. Inst. 
owner or lessee must be obtained even if their lands are not the subject matter of the survey.

There does not appear to be any reported decisions in Canada or the United States dealing with this issue. The American cases referred to above establish that if the survey is conducted from the surface above the petroleum and natural gas rights in question there is an action in trespass unless the owner of the petroleum and natural gas has consented. This is the case even if the surface from which the survey is conducted is owned by a different person and that person has consented. It seems to follow that the petroleum and natural gas owner or lessee should not be deprived of an action in trespass just because the survey is conducted from nearby lands instead of lands immediately above the petroleum and natural gas in question. This would require a court to hold either that no physical entry is required for trespass or that the sound waves emanating from the explosions or other sources are in themselves an entry. The two authors who most recently appear to have addressed this issue suggest that when the fact situation arises the United States courts will dispose of the requirement for a physical trespass. ${ }^{49}$ Since a physical entry is a requirement of a finding of trespass in Canada, it is possible that the Alberta courts, in the above fact situation, will find that the sound waves are a physical entry onto the lands of the petroleum and natural gas owner or lessee. The Alberta cases, Phillips and Reilly, can be distinguished on the basis that the vibrations complained of in those cases were not intended to survey the plaintiff's lands; whereas in the above fact situation, the plaintiff's lands were intended to be part of the survey.

\section{B. AERIAL SURVeY}

The conducting of aerial surveys to detect the potential location of petroleum and natural gas raises difficult issues. If a 3-D seismic program requires the permission of every owner of a right in the petroleum and natural gas to be covered by the survey, perhaps the aerial survey similarly requires the consent of those owners who might be affected. The practical difficulties in obtaining it are substantial.

It is well established in Canada that a structure permanently overhanging a person's lands can be a trespass. ${ }^{\text {so }}$ At least one case has held that whenever the boom of a sky crane swung over the plaintiff's land that a trespass was constituted. ${ }^{\text {s1 }}$ With respect to aircraft, Lacroix v. $R$. established that the owner of land has a limited right to the airspace above it. In that case the plaintiff brought an action in injurious affection for damages respecting a flightway set up over his lands for the Dorval airport. The Court decided that the right of a landowner to the airspace above his lands is limited to what that landowner "can possess or occupy for the use and enjoyment of his land." $\$ 2$ 
There is one helpful reported decision in the United States. In Gulf Coast Real Estate Auction Co. v. Chevron Industries ${ }^{53}$ the defendant conducted an aerial exploration survey over the plaintiff's lands while the two parties were negotiating a possible uranium lease option agreement respecting those lands. Negotiations eventually broke down, and the plaintiff sued for trespass and on an implied contract theory for use and occupation of the lands. The trespass action was dropped when the case was transferred to Federal Court, and the defendant was ultimately successful; however, the court implicitly recognized that there was a cause of action for unauthorized aerial surveys.

If the issue of an unauthorized aerial survey of petroleum and natural gas interests is presented to an Alberta court, the challenge will be to balance the right of the petroleum and natural gas owner or lessee as a landowner with the right to use of airspace for legitimate commercial purposes. The court would also have to consider the benefits to be gained by promoting further minerals exploration in Alberta at a reasonable cost while protecting the right of a landowner to payment for the underground secrets a survey might reveal. Any physical "trespass" over the mineral owner's rights would be temporary, but the results could permanently affect the perception of the value of those minerals and, therefore, impact on the opportunity of the mineral owner to benefit from others who are interested in investigating those minerals and are willing to compensate the owner to get access for ground-based seismic or drilling. If a court finds a trespass is committed when aerial surveying is done without consent, then it will be very difficult to assess damages. It could give rise to an apparent remedy without result. This is an example of technology moving ahead of the status of the law. On balance, the best solution would be to hold that aerial surveying without landowner's consent does not give rise to an action in trespass.

\section{Data Stage}

\section{A. Note On THe Alberta Environment Practice}

The Crown in the right of Alberta, being the largest petroleum and natural gas rights owner and the largest land owner in Alberta, permits gatherers of data to shoot lands and then put the data that is gathered up for auction or for sale prior to the province posting that particular location. Those situations are governed solely by the Crown in right of Alberta.

\section{B. SEISMic Data as Confidential Information ${ }^{54}$}

Throughout all of these relationships, save that of the landowner and the resource owner, there are responsibilities at law governing the use of confidential information. It is clear in Canadian law that the use of confidential information of one party by another party without an express agreement to use that information may result in liability on the party that improperly uses such information. 
Canadian courts have considered circumstances similar to that which may confront an owner of seismic data in the event of another party improperly using that data. In Lac Minerals Ltd. v. International Corona Resources Ltd. ${ }^{\text {ss }}$ a junior mining company, International Corona, was conducting exploratory operations on land on which it held the mining rights. A senior mining company, Lac Minerals, entered into negotiations with the junior for the purpose of a partnership or joint venture between the parties. In the course of negotiations the senior mining company was given access to the data gained in the exploration undertaken by the junior. The senior then used that information to outbid the junior for adjacent property and developed a mine on the adjacent property for its own benefit.

The Supreme Court of Canada held that Lac was under a duty not to misuse that information and that Lac breached that duty by its actions. While not going so far as to find a fiduciary relationship, the Court imposed a constructive trust. In imposing the constructive trust, the Court looked to the principles of both restitution and unjust enrichment. Under the principle of restitution, Corona had been deprived of wealth that, but for the intervening of Lac, would be in the hands of Corona. Under the principle of unjust enrichment, Lac was enriched without any juristic reason for that enrichment. Lac was directed by the Court to transfer the title to the property to Corona.

The Court also considered whether, in the circumstances of the Lac Minerals case, there may have arisen a fiduciary relationship between the parties. The factors used in determining the existence of such a relationship were taken from the dissenting judgment of Wilson J. in Frame v. Smith. ${ }^{56}$ Those factors are as follows:

(1) The fiduciary has scope for the exercise of some discretion or power.

(2) The fiduciary can unilaterally exercise that power or discretion so as to affect the beneficiary's legal or practical interests.

(3) The beneficiary is peculiarly vulnerable to or at the mercy of the fiduciary holding the discretion or power. ${ }^{57}$

The Court in Lac Minerals did not find a fiduciary relationship between Lac and Corona. Indeed, La Forest J. stated that in the situation where there are two arm's-length commercial actors, a fiduciary relationship will not normally arise. The Alberta Court of Appeal decision in Luscar Ltd. v. Pembina Resources Ltd. ${ }^{58}$ further entrenches this principle. The Court decided to limit the relationship between the joint operators to the relationship they had set down in their agreement. The Court put emphasis on the fact that these parties were sophisticated parties who employed lawyers, accountants, and geologists. Although not specifically stated in the case, the fact that the parties were sophisticated may mitigate against a finding of a fiduciary relationship. 
While not wanting to discount the possibility of the courts imposing a fiduciary relationship on parties in the context of the misuse of seismic data, the two foregoing cases found that sophisticated arm's-length commercial parties were not in a fiduciary relationship.

In the American case of Mallon v. Bowen/Edwards ${ }^{59}$ the Colorado Supreme Court was faced with a situation wherein there were competing rights between the plaintiff, as owner of the petroleum and natural gas rights, including coal bed methane, and the defendant, as owner of the coal. The rights were to the same tract of land. The plaintiff had the sole right, given by the Southern Ute Indian tribe ("Tribe"), to conduct geophysical operations on the tract for oil and gas, including coal bed methane. The Tribe had geophysical operations conducted on the tract for coal. There was a responsibility on the plaintiff, in the agreement, to advise the Tribe of any oil. The Tribe had no corresponding responsibility with respect to coal. The Tribe had a government agency conduct geophysical operations, and high amounts of coal bed methane were found on the tract where the plaintiff had gas rights. As was the policy of the government agency, the results of the surveys were made public.

Boyce, the person in charge of the operations with the Tribe, reported the findings to the Tribe and was thereafter retained by the defendant. The data from the operations was then used by the defendant to raise monies to purchase the lands from the plaintiff. At no time was the plaintiff advised of the findings. One year after the sale the plaintiff became aware of the reports and sued for geophysical trespass and fraudulent concealment. Both causes were dismissed by the Colorado Supreme Court.

The Court found that the discovery of coal bed methane was incidental to the search for coal. Coal bed methane is an indicator of coal in a seam and, therefore, necessarily part of the exploration for coal. Additionally, the Court affirmed the right of the Tribe to search for coal. The plaintiff's permission is not needed to explore for coal as their exclusive rights to explore did not contemplate exploration for coal.

Cody Greenwaldt has discussed the issue of fraudulent concealment from the Mallon v. Bowen/Edwards case as follows:

It is a settled rule of law that when a vendor and purchaser of land or goods are dealing at arm's length there is no duty on the part of the purchaser to disclose their quality or merits which he may be able to discover by superior knowledge, and the sale is not fraudulent even though the purchaser knows that the vendor, through ignorance or mistake, is unaware of such qualities and would not have made the sale at the stipulated price had he known of them. ${ }^{60}$

In Canada if the plaintiff had alleged breach of confidence or breach of a fiduciary duty, the courts may not have found any differently. There was no agreement wherein the

6o C.M. Greenwaldt, "Mallon Oil Co. v. Bowen/Edwards Associates Inc.: Delineating the Doctrines of Geophysical Trespass and Fraudulent Concealment in the Coal Exploration Context" (1999) 4 Great Plains Natural Resources Journal 91 at 101. 
plaintiff had rights to information on the coal seam, nor was there a duty on the Tribe to report such findings. Add to this the fact that the information was in the public domain before the sale negotiations had begun and the case may be similar to Luscar Ltd. wherein the Alberta Court of Appeal was unsympathetic to oil and gas companies who, given their level of sophistication, should have known better.

\section{CONCLUSION}

The rules respecting access to Crown surface and Crown petroleum and natural gas in Alberta to conduct seismic exploration are the subject of legislation and are clearly understood. The rules respecting access to freehold surface in Alberta to conduct seismic are governed by legislation and have been subject to some judicial review such that those rules are fairly well understood. The rules governing access to freehold petroleum and natural gas in Alberta to conduct seismic operations are less clear due to a lack of Canadian judicial authority. Cases decided in the United States provide helpful guidance but are very limited in number and are sometimes based on theories of ownership inapplicable in Alberta. Those cases are also fairly old, most of them having been decided in the 1940s and 1950s, and one might have expected that if the issues arising in those cases were going to arise in Canada it would have happened by now. Recent advances in seismic technology have outdistanced all of the judicial authority in Canada, and it will be interesting to see how the Canadian courts deal with some of the issues that could arise from that technology.

The Canadian courts have shown their willingness to prevent the misuse of confidential information, as in Lac Minerals and the cases following that decision. However, there may be a question of whether the oil and gas industry will be held to the same standard as was Lac Minerals, given the sophistication of the parties in the industry as mentioned by the Court of Appeal of Alberta in Luscar Ltd. In the event a party can show that Lac Minerals applies on the facts, there is the added difficulty of proving damages. As with the cases dealing with the advanced technology, it will be interesting to see which of the foregoing cases the courts will more closely adhere to. 